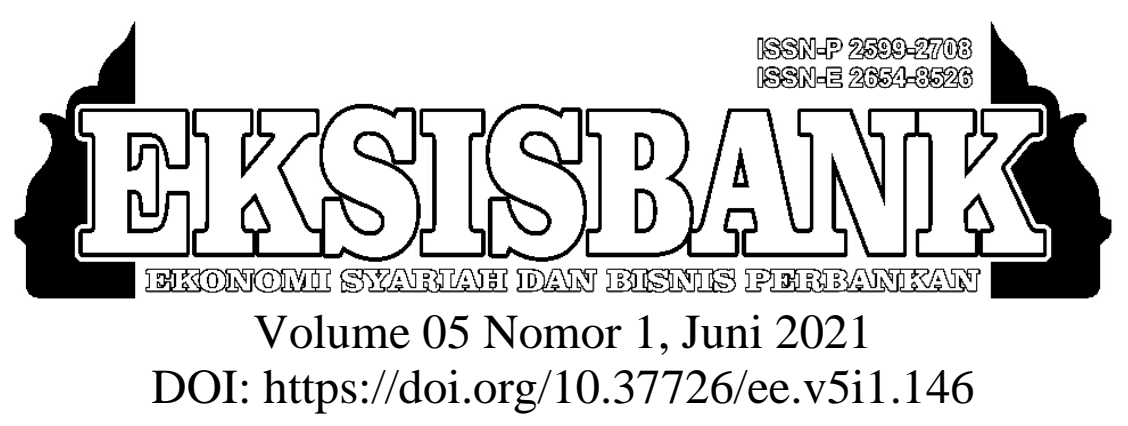

\title{
Akad Tabarru' Pada Pengolahan Limbah Industri di Desa Wantilan Kecamatan Cipeundeuy Subang
}

\author{
Widaningsih $^{1}$, Rina Nurhayati ${ }^{2}$, Siti Rohmat ${ }^{3}$ \\ ${ }^{1}$ Staff Desa Wantilan Cipeundeuy Subang \\ ${ }^{1}$ nengwida63866@gmail.com \\ ${ }^{2,3}$ Sekolah Tinggi Ilmu Ekonomi Syariah (STIES) Indonesia Purwakarta \\ 2inamaza212@gmail.com \\ ${ }^{3}$ sitirohmat38@gmail.com
}

\begin{abstract}
ABSTRAK
Dalam rangka mengurangi sampah dan mengoptimalkan potensi yang ada, Pemerintah Desa Wantilan Mengelola Limbah dari industri berupa Limbah Tali menjadi Produk Kerajinan yang kreatif dan mempunyai nilai ekonomi. Melalui Pembina Kesejahteraan Keluarga (PKK) Desa Wantilan Limbah Tali yang tadinya sampah kini di sulap menjadi tas, tempat Tisu, Pot Bunga dan lainnya. Masyarakat sebagai Pengrajin tentunya memiliki Pendapatan Tambahan dari Produk kerajinan tersebut sehingga Program ini tentu bisa meningkatkan Pendapatan Masyarakat khususnya Ibu-ibu Pengrajin. Tujuan dari penelitian ini adalah untuk mengetahui praktik akad tabarru' pada pengolahan limbah industri di Desa Wantilan Kecamatan Cipeundeuy Kabupaten Subang, untuk mengetahui pengolahan limbah industry yang dijalankan di Desa Wantilan Kecamatan Cipeundeuy dalam pandangan Ekonomi Islam, dan untuk mengetahui manfaat akad tabarru' untuk pengrajin anayaman Desa Wantilan Kecamatan Cieundeuy Kabupaten Subang. Jenis penelitian yang digunakan adalah penelitian lapangan (field research), adapun pendekatan yang digunakan dalam penelitian ini adalah pendekatan deskriptif-kualitatif. Praktik pada pengolahan limbah industri di desa Wantilan adalah akad tabarru' dengan besaran kontribusi uang senilai Rp.10.000,- per karungnya. Pada pengolahan limbah industri di Desa Wantilan terdapat dua akad tabarru' dalam Bentuk memberikan sesuatu (giving something) yaitu akad hibah yang sudah sesuai dengan ketentuan syariah. Adapun manfaat akad Tabarru' yang sudah dilakukan diantaranya adalah Keuntungan hasil penjualan kerajinan cukup besar karena pengrajin tidak perlu membeli bahan baku, Pengrajin dapat dengan mudah mendapatkan bahan baku karena sudah disediakan oleh pengelola, Alat atau pengeluaran umum yang di perlukan oleh PKK untuk kemajuan bersama di bayarkan dari dana tabarru', adapaun keperluan tersebut diantaranya: pembuatan hangtag, keperluan pameran, Pembelian bahan baku ke Perusahaan.
\end{abstract}


Kata kunci-Akad Tabarru', Pengolahan limbah, limbah industri.

\begin{abstract}
In order to reduce waste and optimize existing potential, the Wantilan Village Government manages waste from industry in the form of rope waste into creative handicraft products and has economic value. Through the Family Welfare Trustees (PKK) in Wantilan Village, the waste rope that was previously trash has now been transformed into a bag, a place for tissue, flower pots and others. The community as craftsmen certainly has additional income from these handicraft products so that this program can certainly increase the income of the community, especially the craftswomen. The purpose of this study was to find out the practice of tabarru' contracts in industrial waste treatment in Wantilan Village, Cipeundeuy District, Subang Regency, to find out industrial waste treatment carried out in Wantilan Village, Cipeundeuy District in the view of Islamic Economics, and to find out the benefits of tabarru' contracts for anayaman craftsmen. Wantilan Village, Cieundeuy District, Subang Regency. The type of research used is field research, while the approach used in this research is a descriptive-qualitative approach. The practice of processing industrial waste in Wantilan village is a tabarru contract with a monetary contribution of IDR 10,000 per sack. In industrial waste treatment in Wantilan Village, there are two tabarru' contracts in the form of giving something, namely a grant contract that is in accordance with sharia provisions. The benefits of the Tabarru' contract that have been carried out include the profit from the sale of handicrafts is quite large because craftsmen do not need to buy raw materials, craftsmen can easily get raw materials because they have been provided by the manager, tools or general expenses needed by the PKK for mutual progress in pay from tabarru' funds, as for these needs including: making hangtags, exhibition needs, purchasing raw materials to the company.
\end{abstract}

Keywords - Contract Tabarru', Waste Treatmen, Industrian Waste.

\section{PENDAHULUAN}

Pembangunan Infrastuktur dan industri dari tahun ke tahun sangat pesat, Jalan tol dan Perumahan banyak di bangun dimana-mana sehingga lahan tanah sedikit demi sedikit terus berubah bentuk menjadi bangunan. Desa Wantilan adalah salah satu Desa yang terletak di Kecamatan Cipeundeuy Kabupaten subang, dimana Kecamatan Cipeundeuy ini merupakan Kawasan Industri yang berada di Kabupaten Subang. Perusahaan yang terletak di Desa Wantilan diantaranya yaitu PT. Jesi Jeson Surya Makmur, PT. Anugrah Mutu Bersama (bango), PT Hyundong dan lain-lain. Sebuah Industri Selain Memproduksi Sebuah Produk tentunya Menyisakan Limbah yang harus di kelola dengan baik agar tidak merusak Lingkungan bahkan bisa di manfaatkan kembali menjadi sebuah Produk yang bermanfaat (Zulkarnain, Harianto, and Kirbrandoko 2020). Limbah Industri yang bisa di manfaatkan kembali yaitu salah satunya Limbah Padat. Pemerintah tentunya sangat berperan dalam mengatur semua lingkup yang ada di wilayahnya termasuk berperan aktif dalam pengolahan limbah (Nurhasni, Salimin, and Nurifitriyani 2013).

Akad Tabarru' adalah akad yang dimaksudkan untuk menolong dan murni semata-mata karena mengharapkan ridha dan pahala dari Allah SWT, sama sekali tidak ada unsur mencari keuntungan.

Bertujuan untuk mengurangi sampah dan mengoptimalkan potensi yang ada, Pemerintah Desa Wantilan Mengelola Limbah dari industri berupa Limbah Tali menjadi Produk Kerajinan yang kreatif dan mempunyai nilai ekonomi. Melalui Pembina 
Kesejahteraan Keluarga (PKK) Desa Wantilan Limbah Tali yang tadinya sampah kini di sulap menjadi tas, tempat Tisu, Pot Bunga dan lainnya. Masyarakat sebagai Pengrajin tentunya memiliki Pendapatan Tambahan dari Produk kerajinan tersebut sehingga Program ini tentu bisa meningkatkan Pendapatan Masyarakat khususnya Ibu-ibu Pengrajin.

Hal ini merupakan Pencapaian yang Luar Biasa bagi Pemerintah Desa wantilan karena Pemanfaatan Limbah industri pada pemerintahan sebelumnya tidak maksimal, Anggota Pengrajin hanya menyetorkan uang kas (Dana Tabarru') kepada Bendahara Pembina Kesejahteraan Keluarga (PKK) kemudian bisa membuat kerajinan untuk dijual, keuntungan dari hasil penjualan adalah untuk pengrajin itu sendiri.

\section{A. Pengertian Akad Tabarru'}

Akad tabarru"e (gratuitous contract) adalah segala macam perjanjian yang menyangkut not-for profit transaction (transaksi nirlaba). Transaksi ini pada hakekatnya bukan transaksi bisnis untuk mencari keuntungan komersil (Mardani 2015). Akad tabarrue dilakukan dengan tujuan tolong-menolong dalam rangka berbuat kebaikan (tabarru" berasal dari kata birr dalam bahasa Arab, yang artinya kebaikan). Dalam akad tabarru", pihak yang berbuat kebaikan tersebut tidak berhak mensyaratkan imbalan apapun kepada pihak lainnya. Imbalan dari akad tabarru" adalah dari Allah SWT, bukan dari manusia. Namun demikian, pihak yang berbuat kebaikan tersebut boleh meminta kepada counter-part-nya untuk sekadar menutupi biaya (cover the cost) yang dikeluarkannya untuk dapat melakukan akad tabarru' tersebut. Tapi ia tidak boleh sedikitpun mengambil laba dari akad tabarru' itu. Contoh akad-akad tabarru' adalah qard, rahn, hiwalah, wakalah, kafalah, wadi"ah, hibah, waqf, shadaqah, hadiah, dll.

Akad Tabarru' adalah akad yang dilakukan dalam bentuk hibah dengan tujuan kebajikan dan tolong menolong, bukan untuk tujuan komersial. Dalam akad Tabarru', harus disebutkan sekurang-kurangnya mengenain hak \& kewajiban masing-masing individu (Dewan Syariah Nasional 2006).

\section{B. Dasar Hukum Akad Tabarru'}

Dalam al Quran Allah swt berfirman pada surat Al-Baqarah ayat 177:

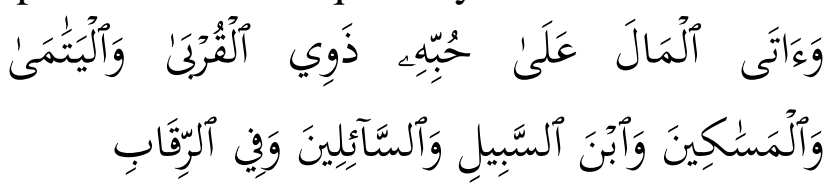

"dan memberikan harta yang dicintainya kepada kerabatnya, anak-anak yatim, orangorang miskin, musafir (yang memerlukan pertolongan)."

\section{Rukun dan Syarat}

a. Pihak penghibah, pihak penghibah disyaratkan:

1. Penghibah harus sebagai pemilik sempurna atas benda yang dihibahkan.

2. Penghibah harus seseorang yang cakap serta sempurna yaitu baligh dan berakal.

3. Penghibah hendaklah melakukan perbuatan atas dasar kemauan sendiri dengan penuh kerelaan dan bukan dalam keadaan terpaksa.

b. Pihak penerima hibah. Pihak penerima hibah disyaratkan sudah wujud, dalam arti yang sesungguhnya ketika akad hibah dilaksanakan.

c. Objek yang dijadikan hibah. Syarat dari objek yang dijadikan hibah yaitu:

1. Benda yang dihibahkan harus milik sempurna dari penghibah.

2. Benda yang dihibahkan sudah ada dalam arti sesungguhnya saat pelaksanaan akad. 
3. Objek yang dihibahkan merupakan sesuatu yang dibolehkan dimiliki oleh agama.

4. Harta yang dihibahkan harus telah terpisah secara jelas dari harta penghibah.

\section{Fungsi dana Tabarru'}

Akad tabarru" ini adalah akad-akad untuk mencari keuntungan akhirat, karena itu bukan akad bisnis. Jadi, akad ini tidak dapat digunakan untuk tujuan-tujuan komersil. Bank Syariah sebagai lembaga keuangan yang bertujuan untuk mendapatkan laba tidak dapat mengandalkan akad-akad tabarru" untuk mendapatkan laba (Oktayani 2018). Bila tujuan kita adalah mendapatkan laba, maka gunakanlah akad-akad yang bersifat komersil, yakni akad tijarah. Namun demikian, bukan berarti akad tabarru" sama sekali tidak dapat digunakan dalam kegiatan komersil. Bahkan pada kenyataanya, penggunaan akad tabarru" sering sangat vital dalam transaksi komersil, karena akad tabarru" ini dapat digunakan untuk menjembatani atau memperlancar akad-akad tijarah (Fauzan 2016).

Tujuan Penelitian ini yaitu untuk menjelaskan atau mendeskripsikan Untuk mengetahui praktik akad tabarru' pada pengolahan limbah Industri di Desa Wantilan Kecamatan Cipeundeuy Kabupaten Subang. dan Untuk mengetahui pengolahan limbah industri yang dijalankan di Desa Wantilan Kecamatan Cipeundeuy Kabupaten Subang dalam pandangan Ekonomi Islam, serta Untuk mengetahui manfaat akad tabarru' untuk pengrajin anyaman Desa Wantilan Kecamatan Cipeundeuy Kabupaten Subang.

\section{TINJAUAN PUSTAKA}

Penelitian tentang Implementasi Akad Tabarru' Pada Pengolahan Limbah Industri sudah banyak dilakukan penelitian oleh peneliti-peneliti sebelumnya, seperti penelitian-penelitian sebagai berikut:

1. Akad Syariah pada Usaha Bank Sampah Aisyiyah di Desa Sejegi Kabupaten Mempawah (Safitri and Bustami 2021)

Penelitian ini bertujuan untuk mengetahui mekanisme usaha bank sampah, akadnya dan manfaat ekonomi usaha bank sampah terhadap peningkatan pendapatan anggota. Penelitian ini melibatkan 50 responden anggota bank sampah Aisyiyah di Desa Sejegi Kabupaten Mempawah, Kalimantan Barat. Hasil penelitian menunjukkan bahwa mekanisme bank sampah 'Aisyiyah berupa jual beli sampah secara langsung dan daur ulang sampah. Akad yang digunakan pada usaha bank sampah adalah berupa jual beli (al-ba'i) dan kerjasama (syirkah). Terdapat pengaruh terhadap kenaikan pendapatan anggota bank sampah 'Aisyiyah, sebagai pendapatan tambahan mereka.

Perbedaan penelitian terdahulu dengan penelitian saat ini adalah peneliti terdahulu tentang Akad Syariah pada Usaha Bank Sampah Aisyiyah yang ada di Desa Sejegi Kabupaten Mempawah, tujuan dari penelitian terdahulu adalah untuk mengetahui mekanisme usaha bank sampah, akadnya dan manfaat ekonomi usaha bank sampah terhadap peningkatan pendapatan anggota. Sedangkan peneliti saat ini tentang Implementasi Akad Tabarru' Pada Pengolahan Limbah Industri di Desa Wantilan Kecamatan Cipeundeuy Kabupaten Subang, adapun limbah industri yang peneliti observasi adalah limbah tali strapping yang dijadikan kreasi unik oleh masyarakat sekitar sehingga menghasilkan sesuatu kerajinan yang bernilai ekonomi, serta peneliti mencoba mengkaji kesesuaian Syariah atau tidaknya terhadap praktek-praktek tolong-menolong atau akad Tabarru'iyah yang dilakukan pengelola limbah dengan masyarakat Desa Wantilan Kecamatan Cipeundeuy Kabupaten 
Subang. Persamaannya dengan peneliti terdahulu adalah sama-sama mengelola sampah menjadi sesuatu yang unik dan bernilai ekonomi.

\section{Jual Beli Barang Bekas Melalui Bank}

Sampah Perspektif Hukum Ekonomi

Syariah (Arifin 2021)

Penelitian ini dilakukan untuk menjelaskan tentang praktik jual barang bekas melalui bank sampah. Penelitian ini bertujuan untuk menggambarkan dengan jelas mengenai praktik jual beli barang bekas melalui bank sampah di Kecamatan Sajad dan tinjauan hukum Islam terhadap jual beli barang bekas melalui bank sampah di Kecamatan Sajad. Berdasarkan hasil penelitian menyimpulkan bahwa praktik jual beli barang bekas melalui bank sampah diKecamatan Sajad sudah memenuhi rukun dan syarat jual beli dan dilakukan atas dasar suka sama suka serta tidak ada pihak yang merasa dirugikan. Tinjauan hukum ekonomi syariah terhadap jual beli barang bekas melalui bank sampahtermasuk jual beli yang sah karena dari segi kesucian barang bekas yang dijual di bank sampah merupakan barang yang suci dan untuk barang bekas sesuai dengan pendapatulama Hanafiyah memperbolehkan jual beli barang yang terkena najis bukan untuk dimakan. Dari segi harga dalam jual beli barang bekas telah terdapat kesepakatan antara kedua belah pihak dan tidak ada yang dirugikan.

Perbedaan penelitian terdahulu dengan penelitian saat ini adalah peneliti terdahulu menganalisis Jual Beli Barang Bekas Melalui Bank Sampah dalam Perspektif Hukum Ekonomi Syariah, tujuan dari penelitian terdahulu adalah untuk menggambarkan dengan jelas mengenai praktik jual beli barang bekas melalui bank sampah di Kecamatan Sajad dan tinjauan hukum Islamterhadap jual beli barang bekas melalui bank sampah di
Kecamatan Sajad. Sedangkan peneliti saat ini tentang Implementasi Akad Tabarru' Pada Pengolahan Limbah Industri di Desa Wantilan Kecamatan Cipeundeuy Kabupaten Subang, adapun limbah industri yang peneliti observasi adalah limbah tali strapping yang dijadikan kreasi unik oleh masyarakat sekitar sehingga menghasilkan sesuatu kerajinan yang bernilai ekonomi, serta peneliti mencoba mengkaji kesesuaian Syariah atau tidaknya terhadap praktek-praktek tolong-menolong atau akad Tabarru'iyah yang dilakukan pengelola limbah dengan masyarakat Desa Wantilan Kecamatan Cipeundeuy Kabupaten Subang. Persamaannya dengan peneliti terdahulu adalah sama-sama mengelola sampah menjadi sesuatu yang unik dan bernilai ekonomi.

3. Komersialisasi Pupuk Kandang Dalam Prespektif Hukum Islam (Alfin and Rezi 2019)

Komersialisasi (Jual beli) pupuk kandang menjadi salah satu masalah yang diperselisihkan status hukumnya di kalangan Ulama. Ulama Hanafiyah membolehkan pemanfaatan dan jual beli pupuk kandang sekalipun hukumnya najis. Ulama syafi'iyah menganggap makruh menggunakan pupuk kandang karena najis, dan tidak membolehkannya menjadikan pupuk kandang sebagai objek jual beli, tapi boleh dengan akad pengguguran hak. Ulama Malikkiyah dan Hanabilah membolehkan pemanfaatan dan penjualan pupuk kandang yang berasal dari hewan yang halal dan mengharamkan untuk hewan yang haram dimakan. Dalam tataran implementatif, keluar dari khilaf adalah hal yang lebih baik. Maka menggunakan akad ijarah 'ala al-manfaah (upah mengupah) merupakan jalan keluar yang dapat ditempuh.

Perbedaan penelitian terdahulu dengan penelitian saat ini adalah peneliti terdahulu menganalisis Komersialisasi Pupuk Kandang 
Dalam Prespektif Hukum Islam. Sedangkan peneliti saat ini tentang Implementasi Akad Tabarru' Pada Pengolahan Limbah Industri di Desa Wantilan Kecamatan Cipeundeuy Kabupaten Subang. Perbedaan lainnya terdapat pada objek penelitiannya, peneliti terdahulu limbahnya adalah limbah kotoran hewan, sedangkan pada peneliti saat ini limbah yang dijadikan objek penelitian adalah limbah pabrik yanitu berupa tali strapping.

\section{Eksistensi Dan Optimalisasi Badan Usaha} Milik Desa (BUMDes) Berbasis Syar'i Menuju Desa Sejahtera Mandiri (Subhan 2020)

Perkembangan beberapa desa di Indonesia pada dekade akhir-akhir ini menunjukkan perkembangan yang luar biasa. Desa yang selama ini identik dengan keterbelakangan dan kemiskinan, secara perlahan namun pasti mulai bangkit dan berkembang. Hal tersebut ditandai dengan menurunnya kategori desa sangat tertinggal atau desa tertinggal menjadi desa berkembang, maju dan mandiri. Desa diharapkan dapat menjadi mandiri secara sosial, budaya, ekonomi dan politik. Kemandirian desa merupakan kondisi dimana desa tersebut memiliki kemampuan melakukan pembangunan di segala sektor untuk peningkatan kualitas hidup dan sebesarbesarnya untuk kesejahteraan masyarakat desa. Kemandirian desa dibuktikan dengan adanya kemampuan desa untuk memenuhi kebutuhannya sendiri dan tidak semata-mata tergantung dengan subsidi dari pemerintah, meskipun desa menerima bantuan pemerintah tapi sifatnya hanya sebagai stimulan. salah satu cara mendorong pembangunan pada tingkat desa, yaitu dengan memberikan wewenang pada pemerintah desa untuk mengelola secara mandiri lingkup desa melalui lembaga-lembaga ekonomi di tingkat desa. Salah satunya adalah dengan mengembangkan dan mengelola secara optimal Badan Usaha Milik Desa (BUMDes) secara syar'i, melalui akad-akad yang berbasis ekonomi islam. Jika BUMDes berbasis syar'i mampu berjalan dengan baik, terlebih mampu meningkatkan pendapatan asli desa dan mengurangi pengangguran, maka kedepannnya desa akan semakin sejahtera dan mandiri.

Perbedaan penelitian terdahulu dengan penelitian saat ini adalah peneliti terdahulu menganalisis Eksistensi Dan Optimalisasi Badan Usaha Milik Desa (BUMDes) Berbasis Syar'i Menuju Desa Sejahtera Mandiri. Peneliti terdahulu mempunyai tujuan Desa diharapkan dapat menjadi mandiri secara sosial, budaya, ekonomi dan politik, Desa yang selama ini identik dengan keterbelakangan dan kemiskinan. Sedangkan peneliti saat ini tentang Implementasi Akad Tabarru' Pada Pengolahan Limbah Industri di Desa Wantilan Kecamatan Cipeundeuy Kabupaten Subang. Perbedaan lainnya terdapat pada tujuan dari penelitian yang dilakukan, penelitian saat ini mempunyai tujuan untuk mengetahui praktik akad tabarru' pada pengolahan limbah industri di Desa Wantilan Kecamatan Cipeundeuy Kabupaten Subang, untuk mengetahui pengolahan limbah industry yang dijalankan di Desa Wantilan Kecamatan Cipeundeuy dalam pandangan Ekonomi Islam, dan untuk mengetahui manfaat akad tabarru' untuk pengrajin anayaman Desa Wantilan Kecamatan Cieundeuy Kabupaten Subang.

\section{Manajemen Pengelolaan Limbah Industri} (Nasir, Saputro, and Handayani 2015)

Limbah industri merupakan salah satu masalah serius di era industrialisasi. Oleh karena itu pengelolaan limbah harus ditangani sejak awal selama proses produksi. Artinya, proses pengolahan sampah harus dilakukan dari hulu hingga hilir. Penelitian ini bertujuan untuk membentuk model optimasi 
pengelolaan sampah dengan analisis kuantitatif yang dilakukan melalui diskusi kelompok terfokus dan wawancara mendalam yang menggabungkan suara produsen dan suara pelanggan. Hasil penelitian menunjukkan banyaknya aspek yang terkait dengan limbah dari industri tahu di Kartasura, maka optimalisasi limbah menjadi sangat penting. Hasil penelitian ini tidak dapat menyelesaikan semua permasalahan, maka terdapat keterbatasan dan penelitian lebih lanjut, dan saran diperlukan untuk penelitian ini.

Perbedaan penelitian terdahulu dengan penelitian saat ini adalah peneliti terdahulu Manajemen Pengelolaan Limbah Industri. Peneliti terdahulu mempunyai tujuan untuk membentuk model optimasi pengelolaan sampah dengan analisis kuantitatif yang dilakukan melalui diskusi kelompok terfokus dan wawancara mendalam yang menggabungkan suara produsen dan suara pelanggan. Sedangkan peneliti saat ini tentang Implementasi Akad Tabarru' Pada Pengolahan Limbah Industri di Desa Wantilan Kecamatan Cipeundeuy Kabupaten Subang. Perbedaan lainnya terdapat pada tujuan dari penelitian yang dilakukan, penelitian saat ini mempunyai tujuan untuk mengetahui praktik akad tabarru' pada pengolahan limbah industri di Desa Wantilan Kecamatan Cipeundeuy Kabupaten Subang, untuk mengetahui pengolahan limbah industry yang dijalankan di Desa Wantilan Kecamatan Cipeundeuy dalam pandangan Ekonomi Islam, dan untuk mengetahui manfaat akad tabarru' untuk pengrajin anayaman Desa Wantilan Kecamatan Cieundeuy Kabupaten Subang.

\section{Model Pengolahan Limbah Plastik OPP} Laminasi Menjadi Produk Aksesoris Fesyen (Santoso and Widyamurti 2020)

Plastik OPP Laminasi merupakan limbah produk industri percetakan yang banyak sekali berkembang di Solo Raya. Plastik OPP sebagai salah satu bahan baku laminasi biasanya digunakan sebagai laminasi sampul buku, kotak kemasan, dan sejenisnya, sehingga awet dan tampil lebih menarik. Akan tetapi, di sisi lain, industri percetakan menghasilkan limbah yang merugikan lingkungan, karena menghasilkan limbah baik padat maupun limbah cair dan belum pernah menerapkan sistem pengolahan atas limbah tersebut. Penelitian Kualitatif ini dilakukan dengan metode Action Research atas limbah Plastik OPP Laminasi yang dihasilkan oleh industri percetakan di Solo Raya yang belum pernah diolah menjadi produk yang bermanfaat. Tujuannya adalah untuk mengolah limbah Plastik OPP Laminasi menjadi bahan baku produk aksesoris fesyen berupa tas, dompet dan alas kaki. Hasil penelitian ini berupa produk basket bag, cluch bag, pouch, sepatu dan sandal yang bisa dikembangkan menjadi program kemitraan dengan pengrajin dan kewirausahaan mahasiswa untuk mendukung industri kreatif. Tujuan kegiatan penelitian ini dilaksanakan dengan konsep upcycle limbah Plastik OPP Laminasi menjadi produk aksesoris fesyen yang bernilai ekonomis tinggi melalui teknik tekstil.

Perbedaan penelitian terdahulu dengan penelitian saat ini adalah peneliti terdahulu mengalisis Model Pengolahan Limbah Plastik OPP Laminasi Menjadi Produk Aksesoris Fesyen. Peneliti terdahulu mempunyai tujuan untuk mengolah limbah Plastik OPP Laminasi menjadi bahan baku produk aksesoris fesyen berupa tas, dompet dan alas kaki. Sedangkan peneliti saat ini tentang Implementasi Akad Tabarru' Pada Pengolahan Limbah Industri di Desa Wantilan Kecamatan Cipeundeuy Kabupaten Subang. Perbedaan lainnya terdapat pada tujuan dari penelitian yang dilakukan, penelitian saat ini mempunyai tujuan untuk mengetahui praktik akad tabarru' 
pada pengolahan limbah industri di Desa Wantilan Kecamatan Cipeundeuy Kabupaten Subang, untuk mengetahui pengolahan limbah industry yang dijalankan di Desa Wantilan Kecamatan Cipeundeuy dalam pandangan Ekonomi Islam, dan untuk mengetahui manfaat akad tabarru' untuk pengrajin anayaman Desa Wantilan Kecamatan Cieundeuy Kabupaten Subang. Persamaannya dengan peneliti terdahulu adalah sama-sama mengelola sampah menjadi sesuatu yang unik dan bernilai ekonomi.

\section{METODOLOGI PENELITIAN}

Dalam penelitian ini metode yang di gunakan adalah Pendekatan Kualitatif. Metode penelitian kualitatif adalah metode penelitian yang berlandaskan pada filsafat postpositivisme,di gunakan untuk meneliti pada kondisi objek yang alamiah, dimana peneliti adalah instrument kunci, teknik pengeumpulan data di lakukan secara triangulasi (gabungan), analisis data bersifat kualitatif, dan hasil penelitian kualitatif lebih menekankan makna daripada generalisasi. Berikut ini ada beberapa teknik pengumpulan data:

\section{A. Wawancara}

Susan Stainback dalam buku sugiono mengemukakan, dengan wawancara, maka peneliti akan mengetahui hal-hal yang lebih mendalam tentang partisipan dalam menginterprestasikan situasidan fenomena yang terjadi (Sugiyono 2017). Wawancara pada penelitian ini dilakukan secara tidak terstruktur, dimana penulis tidak menggunakan pedoman wawancara saat mewawancarai sumber data. Tujuannya yaitu untuk mendapatkan informasi lebih dalam karena lebih banyak mendengarkan apa yang diceritakan oleh responden. Sumber data yang dipilih saat melakukan wawancara yaitu Kepala Desa Wantilan yaitu Bapak Komarudin, S.Pd, Sekertaris Desa Wantilan yaitu bapak Lili Suherli,dan ketua kordinator pengolahan limbah industri yaitu ibu Yuyu Yunengsih.

\section{B. Observasi}

Observasi adalah dasar semua ilmu pengetahuan. yang penulis lakukan adalah observasi parsitipatif . dalam observasi partisipatif peneliti terlibat dalam kegiatan sehari-hari orang yang sedang diamati atau yang digunakan sebagai sumber data dan ikut merasakan suka dukanya.. dalam penelitian ini penulis ikut melakukan apa yang sumber data kerjakan, penulis ikut belajar menganyam bersama pengrajin untuk memperoleh data yang lebih tajam dan mengetahui masalah apa yang dihadapi oleh para pengrajin.

C. Dokumentasi

Dokumen adalah catatan peristiwa yang sudah berlalu (Sugiyono 2006). Dokumentasi sangat penting agar hasil dari observasi dan wawancara lebih kredibel. Adapun dokumentasi yang penulis dapatkan beberapa diantaranya yaitu:

1. Foto kegiatan pengrajin

2. Struktur organisasi Desa wantilan

3. Data masyarakat Desa Wantilan

Sumber data dalam penelitian adalah subyek dari mana data dapat di peroleh. Apabila peneliti menggunakan kuesioner atau wawancara dalam pengumpulan datanya, maka sumber data disebut narasumber, yaitu orang yang yang merespon atau menjawab pertanyaan peneliti baik pertanyaan tertulis atau lisan. Apabila peneliti menggunakan teknik observasi, maka sumber datanya berupa benda, gerak atau proses sesuatu. Apabila peneliti menggunakan dokumentasi maka dokumen atau catatan yang menjadi sumber data sedang isi catatan subjek penelitian atau variabel penelitian (Sugiyono 2018):

\section{Data Primer}


Sumber Primer yaitu sumber data yang langsung memberikan data kepada Pengumpul data (Sugiyono 2006). Sumber Primer yang memberikan data kepada penulis yaitu Bapak Kepala Desa Wantilan, Komarudin, S.Pd. Bapak Sekertaris Desa Wantilan, Bapak Lili Suherli dan Ibu Yuyu Yunengsih sebagai Ketua UPPKS TP PKK (Usaha Peningkatan Pendapatan Keluarga Sejahtera Tim Penggerak Pemberdayaan dan Kesejateraan Keluarga) dalam Pengolahan Limbah industri menjadi kerajinan dengan melakukan wawancara, Observasi, dan dokumentasi.

2. Data Sekunder

Sumber sekunder yaitu sumber yang tidak langsung mengumpulkan data kepada pengumpul data (Sugiyono 2013). Sumber sekunder penulis memperolehnya dari dokumen desa, Dokumentasi pada saat observasi Buku, Jurnal para ahli yang membahas tentang Akad tabarru'.

Analisis adalah proses mencari dan menyusun secara sistematis data yang diperoleh dari hasil wawancara, catatan lapangan, dan dokumentasi dengan cara mngorganisasikan data ke dalam kategori, mejabarkan ke dalam unit-unit, melakukan sintesa, menyusun ke dalam pola, memilih mana yang penting dan yang akan dipelajari, dan membuat kesimpulan sehingga mudah difahami oleh diri sendiri maupun orang lain (Sugiyono 2013). Penulis akan mendeskripsikan data yang sudah di dapatkan, diantaranya yaitu:

1. Proses pelaksanaan akad tabarru' di Desa Wantilan

2. Manfaat akad tabarru' bagi bagi pengrajn

3. Akad tabarru untuk kemaslahatan masyarakat

Keabsahan data dalam penelitian ini ditentukan dengan menggunakan kriteria kredibilitas. Untuk mendapatkan data yang relevan, maka peneliti melakukan pengecekan keabsahan data hasil penelitian dengan cara:

a) Perpanjangan Pengamatan

Perpanjangan pengamatan berarti peneliti kembali ke lapangan, melakukan pengamatan, wawancara lagi dengan sumber data yang pernah ditemui maupun yang baru (Sugiyono 2018). Dengan perpanjangan pengamatan ini, peneliti mengecek kembali apakah data yang telah diberikan selama ini setelah dicek kembali pada sumber data asli atau sumber data lain ternyata tidak benar.

b) Ketekunan Pengamatan

Meningkatkan ketekunan berarti melakukan pengamatan secara lebih cermat dan berkesinambungan. Dengan cara tersebut maka kepastian data dan urutan peristiwa akan dapat direkam secara pasti dan sistematis (Sugiyono 2015). Meningkatkan ketekunan itu ibarat kita mengecek soal- soal, atau makalah yang telah dikerjakan, apakah ada yang salah atau tidak. Dengan meningkatkan ketekunan itu, maka peneliti dapat melakukan pengecekan kembali apakah data yang telah ditemukan itu salah atau tidak. Demikian juga dengan meningkatkan ketekunan maka, peneliti dapat memberikan deskripsi data yang akurat dan sistematis tentang apa yang diamati (Sugiyono 2015). Sebagai bekal peneliti untuk meningkatkan ketekunan adalah dengan cara membaca berbagai referensi buku maupun hasil penelitian atau dokumentasi-dokumentasi yang terkait dengan mekanisme akad tabarru'

c) Triangulasi

Triangulasi dalam pengujian kredibilitas ini diartikan sebagai pengecekan data dari berbagai sumber dengan berbagai cara, dan berbagai waktu. Dengan demikian terdapat triangulasi sumber, triangulasi teknik pengumpulan data, dan waktu (Sugiyono 2018). Dalam penelitian ini menggunakan triangulasi sumber. Triangulasi sumber digunakan untuk pengecekan data tentang 
keabsahannya, membandingkan hasil wawancara dengan isi suatu dokumen dengan memanfaatkan berbagai sumber data informasi sebagai bahan pertimbangan. Dalam hal ini penulis membandingkan data hasil observasi dengan data hasil wawancara, dan juga membandingkan hasil wawancara dengan wawancara lainnya.

\section{HASIL DAN PEMBAHASAN}

A. Praktik akad Tabarru' pada pengolahan Limbah Industri di Desa Wantilan Kecamatan Cipeundeuy Kabupaten

\section{Subang}

\section{Kontribusi}

Dalam wawancara tersebut Ibu Yuyu menjelaskan bahwa

"Besaran kontribusi atau uang kas (hibah) yang dibayarkan adalah Rp. 10.000,- per karung. Uang tersebut di bayarkan ketika pengrajin mengambil bahan baku yang disediakan di kantor PKK (Pemberdayaan Kesejahteraan Keluarga). Aturan tersebut sebelumnya sudah disepakati bersama karena tujuannya pun juga untuk kepentingan bersama" (Yuyun 2019).

Dalam pelaksanaan akad tabarru' ini sebelumnya tidak ada syarat apapun untuk menjadi keanggotaan pengrajin selama orang tersebut adalah masyarakat Desa Wantilan.Dana hibah yang di bayarkan semuanya di kumpulkan di Bendahara PKK Desa Wantillan, Ibu Yuliati sebagai penerima hibah untuk disimpan dan dikelola sebagaimana kesepakatan.

Dari keterangan diatas penulis menyimpulkan bahwa aqid atau orang yang berakad adalah pengrajin dan pengelola PKK. Pengrajin adalah pihak penghibah tetapi dengan syarat orang tersebut adalah masyarakat Desa Wantilan, pengelola atau bendahara PKK adalah pihak penerima hibah. Objek yang di jadikan hibah adalah sebesar
Rp.10.000,- dan bahan baku pembuatan kerajinan.

\section{Keuntungan}

Dalam praktiknya kedua belah pihak tidak ada yang dirugikan, pengelola hanya menghimpun dana hibah tersebut untuk keperluan kegiatan PKK itu sendiri. Pengrajin dengan mengeluarkan dana Hibah tersebut, bisa mendapatkan bahan baku kerajinan sebanyak satu karung dan bisa di produksi menjadi beberapa produk.

Sebagaimana yang sudah di jelaskan pada bab sebelumnya bahwa Akad tabarru' dilakukan dengan tujuan tolong-menolong dalam rangka berbuat kebaikan (tabarru' berasal dari kata birr dalam bahasa Arab, yang artinya kebaikan). Dalam akad tabarru', pihak yang berbuat kebaikan tersebut tidak berhak mensyaratkan imbalan apapun kepada pihak lainnya. Imbalan dari akad tabarru' adalah dari Allah SWT, bukan dari manusia. Namun demikian, pihak yang berbuat kebaikan tersebut boleh meminta kepada counter-part-nya untuk sekadar menutupi biaya (cover the cost) yang dikeluarkannya untuk dapat melakukan akad tabarru' tersebut. Tapi ia tidak boleh sedikitpun mengambil laba dari akad tabarru' itu. Contoh akad-akad tabarru' adalah qard, rahn, hiwalah, wakalah, kafalah, wadi"ah, hibah, waqf, shadaqah, hadiah, dll (Rafsanjani 2016).

Dari keterangan diatas penulis bisa simpulkan bahwa Praktik yang di lakukan pada pengolahan limbah industri ini adalah akad hibah.

\section{Alur Praktik Pelaksanaan Akad Tabarru}

Adapun jika digambarkan, alur praktik pelaksanaan Akad ta barru' adalah sebagai berikut:

Bagan 4.1

Alur pengolahan limbah industri di Desa Wantilan 


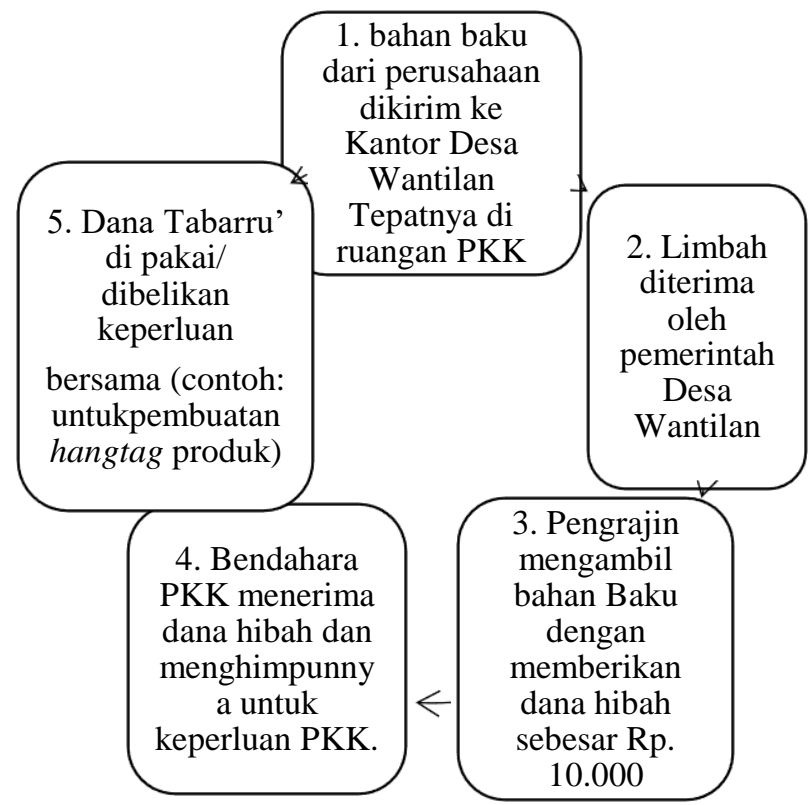

Sumber: Hasil wawancara dan observasi penulis, diolah oleh penulis, 2019.

Perusahaan yang menyalurkan Limbahnya yaitu PT.Anugrah Mutu Bersama yang berlokasi di Desa Wantilan. Limbah tersebut adalah limbah padat berupa tali yang bisa di anyam dan menjadi produk tas, tempat tissue, pot, dan lain sebagainya. Pengiriman dari perusahaan tidak dikirim rutin, tapi sesuai dengan bahan yang dibutuhkan, jika sudah habis, maka pihak PKK menghubungi pihak perusahaan.

Setelah bahan baku kerajinan sudah tersedia, maka pengrajin boleh mengambil bahan baku tersebut di kantor Desa Wantilan dengan memberikan dana hibah sebesar Rp. 10.000,- per karungnya untuk kemudian di produksi. Adapun jika pengrajin tersebut tidak mampu dalam mengeluarkan uang hibah sebesar Rp. 10.000,- maka tidak apa-apa, pengrajin tetap boleh mengambil bahan baku kerajinan.

Berdasarkan wawancara dengan sekertaris Desa Bapak Lili Hambali,

"Setiap RW di desa wantilan sudah ada pengrajinnya, hanya saja ada yang fokus untuk di kembangkan, ada juga yang hanya sekedar belajar. Adapaun fasilitas yang diberikan oleh Desa Wantilan juga mengadakan pelatihan secara gratis. Asalkan ada kemauan dari masyarakat itu sendiri" (Hambali 2019).

Adapun dalam pengemasan produk, pengrajin sudah memiliki brand yang bernama 'jemari' . jika penjualan memlalui pengiriman, produk sudah dikemas dengan plastik supaya terlihat rapi dan baru, meski terbuat dari limbah, produk tas yang dibuat sangat cantik.

Karena sudah memiliki brand, tentunya pengrajin sudah membuat hangtag untuk produk, hangtag ini berfungsi untuk melambangkan identitas dari produk tersebut. Hangtag harusnya dibuat dengan rapi dari bahan yang tebal supaya tetap kokoh Ketika di pasang pada produk. Berikut adalah saran dan masukan dari penulis untuk pembuatan hangtag pada produk jemari.

\section{Gambar 4.1 \\ Hangtag Produk}
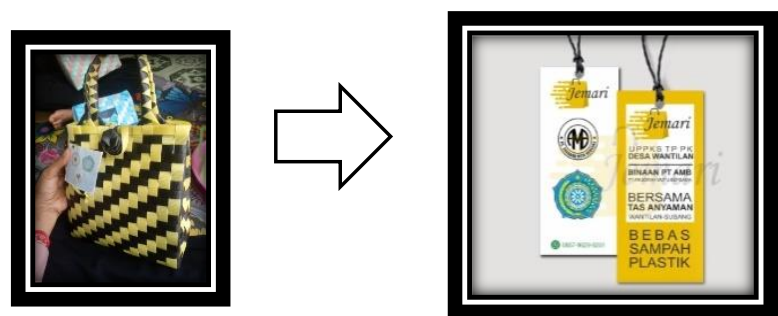

Sumber: hasil observasi penulis, 2019.

Adapun alur pembuatan produk kerajinan dari bahan baku sampai menjadi produk yang bermanfaat dan bernilai ekonomi seperti tas, tempat tissue, pot bunga dan lainnya tidak terlalu rumit hanya membutuhkan teknik menganyam dan kesabaran. Bahan baku yang dibutuhkan yaitu limbah tali yang sudah dibersihkan, penjepit, cetakan tas (dibuat custom sesuai keinginan, bisa dari bahan apa saja) dan gunting. Cara pembuatannya adalah sebagai berikut:

\section{Gambar 4.2}




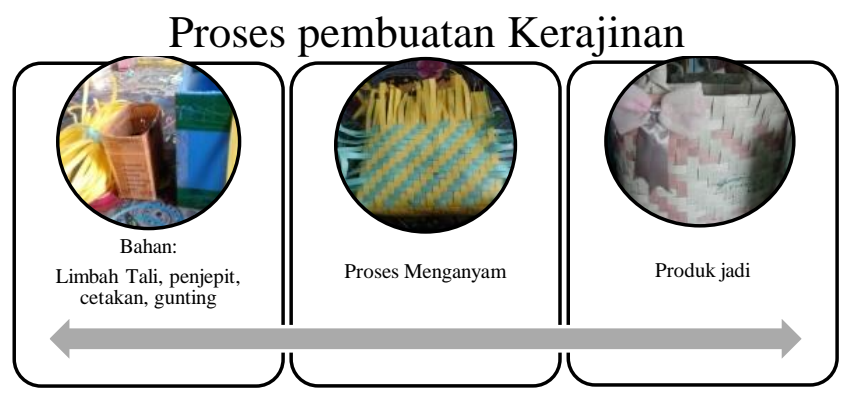

Sumber: hasil observasi penulis, 2019.

B. Pengolahan Limbah Industri yang Dijalankan di Desa Wantilan Kecamatan Cipeundeuy Kabupaten Subang dalam pandangan ekonomi Islam

Tabel 4.1

Analisis Rukun dan syarat hibah

\begin{tabular}{|c|c|c|}
\hline \multirow{2}{*}{$\begin{array}{l}\text { Ketentuan tentang } \\
\text { para pihak }\end{array}$} & \multicolumn{2}{|c|}{$\begin{array}{c}\text { Pandangan } \\
\text { Ekonomi Syariah }\end{array}$} \\
\hline & Syariah & $\begin{array}{c}\text { Tidak } \\
\text { Syariah }\end{array}$ \\
\hline \begin{tabular}{|lr} 
1. Penghibah & harus \\
sebagai & pemilik \\
sempurna & atas \\
benda & yang \\
dihibahkan & \\
\end{tabular} & $\sqrt{ }$ & \\
\hline \begin{tabular}{|lr} 
2. Penghibah & harus \\
seseorang & yang \\
cakap & serta \\
sempurna & yaitu \\
baligh dan berakal
\end{tabular} & $\sqrt{ }$ & \\
\hline \begin{tabular}{|l} 
3. Penghibah \\
hendaklah \\
melakukan \\
perbuatan atas \\
dasar kemauan \\
sendiri dengan \\
penuh kerelaan dan \\
bukan dalam \\
keadaan terpaksa \\
\end{tabular} & $\sqrt{ }$ & \\
\hline $\begin{array}{l}\text { 4. Pihak penerima } \\
\text { hibah disyaratkan } \\
\text { sudah wujud, dalam } \\
\text { arti yang } \\
\text { sesungguhnya }\end{array}$ & $\sqrt{ }$ & \\
\hline
\end{tabular}

\begin{tabular}{|c|c|c|}
\hline \multirow{2}{*}{$\begin{array}{c}\text { Ketentuan tentang } \\
\text { para pihak }\end{array}$} & \multicolumn{2}{|c|}{$\begin{array}{c}\text { Pandangan } \\
\text { Ekonomi Syariah }\end{array}$} \\
\cline { 2 - 3 } & Syariah & $\begin{array}{c}\text { Tidak } \\
\text { Syariah }\end{array}$ \\
\hline $\begin{array}{c}\text { ketika akad hibah } \\
\text { dilaksanakan }\end{array}$ & & \\
\hline
\end{tabular}

Sumber: diolah oleh penulis, 2020

Ketentuan pertama terkait penghibah harus sebagai pemilik sempurna atas benda yang dihibahkan sudah sesuai syariah. Karena berdasarkan hasil analisis dan wawancara bahwa penghibah di Desa Wantilan adalah pemerintah desa wantilan.

Ketentuan kedua terkait penghibah harus seseorang yang cakap serta sempurna yaitu baligh dan berakal sudah sesuai Syariah . karena berdasarkan hasil analisis dan wawancara bahwa penghibah adalah Lembaga yang di dalamnya adalah orangorang baligh dan berakal.

Ketentuan ketiga terkait penghibah hendaklah melakukan perbuatan atas dasar kemauan sendiri dengan penuh kerelaan dan bukan dalam keadaan terpaksa sudah sesuai Syariah . karena berdasarkan dari hasil analisis dan wawancara bahwa penghibah tidak melakukan hibah dengan terpaksa.

Ketentuan keempat pihak penerima hibah disyaratkan sudah wujud, dalam arti yang sesungguhnya ketika akad hibah dilaksanakan sudah sesuai Syariah. Karena berdasarkan hasil analisis dan wawancara bahwa penerima hibah menerima objek hibah secara langsung.

Tabel 4.2

Analisis Rukun dan syarat hibah

\begin{tabular}{|c|c|c|}
\hline \multirow{2}{*}{$\begin{array}{c}\text { Ketentuan tentang } \\
\text { objek hibah }\end{array}$} & \multicolumn{2}{|c|}{$\begin{array}{c}\text { Pandangan } \\
\text { Ekonomi Syariah }\end{array}$} \\
\hline & Syariah & $\begin{array}{l}\text { Tidak } \\
\text { Svariah }\end{array}$ \\
\hline $\begin{array}{ll}\text { 1. Benda } & \text { yang } \\
\text { dihibahkan } & \text { harus }\end{array}$ & $\sqrt{ }$ & \\
\hline
\end{tabular}

EKSISBANK (Ekonomi Syariah dan Bisnis Perbankan), Volume 5, Nomor 1, Juni 2021 


\begin{tabular}{|l|c|c|}
\hline \multirow{2}{*}{$\begin{array}{c}\text { Ketentuan tentang } \\
\text { objek hibah }\end{array}$} & \multicolumn{2}{|c|}{$\begin{array}{c}\text { Pandangan } \\
\text { Ekonomi Syariah }\end{array}$} \\
\cline { 2 - 3 } & Syariah & $\begin{array}{c}\text { Tidak } \\
\text { Syariah }\end{array}$ \\
\hline $\begin{array}{l}\text { milik sempurna dari } \\
\text { penghibah }\end{array}$ & & \\
\hline $\begin{array}{l}\text { 2. Benda yang } \\
\text { dihibahkan sudah } \\
\text { ada, dalam arti } \\
\text { sesungguhnya saat } \\
\text { pelaksanaan akad }\end{array}$ & $\sqrt{ }$ & \\
\hline $\begin{array}{l}\text { 3. Harta yang } \\
\text { dihibahkan harus } \\
\text { terpisah secara jelas } \\
\text { dari harta penghibah }\end{array}$ & $\sqrt{ }$ & \\
\hline
\end{tabular}

Sumber: diolah oleh penulis, 2020

Ketentuan pertama terkait objek hibah Benda yang dihibahkan harus milik sempurna dari penghibah sudah Syariah. Karena berdasarkan hasil analisis dan wawancara bahwa objek hibah adalah milik pemerintah desa wantilan.

Ketentuan kedua terkait benda yang dihibahkan sudah ada, dalam arti sesungguhnya saat pelaksanaan akad sudah Syariah. Karena berdasarkan hasil analisis dan wawancara objek hibah langsung diberikan kepada penerima hibah.

Ketentuan ketiga terkait harta yang dihibahkan harus terpisah secara jelas dari harta penghibah sudah Syariah. Karena berdasarkan hasil analisis dan wawancara objek hibah terpisah jelas dari harta lain pemerintah desa wantilan.

Tabel 4.3

Analisis Rukun dan syarat hibah

\begin{tabular}{|c|c|c|}
\hline \multirow{2}{*}{$\begin{array}{c}\text { Ketentuan tentang } \\
\text { Akad atau ijab } \\
\text { qobul hibah }\end{array}$} & \multicolumn{2}{|c|}{$\begin{array}{c}\text { Pandangan Ekonomi } \\
\text { Syariah }\end{array}$} \\
\cline { 2 - 3 } & Syariah & $\begin{array}{c}\text { Tidak } \\
\text { Syariah }\end{array}$ \\
\hline $\begin{array}{l}\text { Dari akad sudah } \\
\text { disepakati di awal } \\
\text { dan dilakukan pada } \\
\text { saat akad } \\
\text { berlangsung }\end{array}$ & $\sqrt{ }$ & \\
\hline
\end{tabular}

Sumber: diolah oleh penulis, 2020

Ketentuan terkait Akad atau Ijab qobul sudah Syariah. Karena berdasarkan analisis dan wawancara bahwa ijab qobul sudah dilaksanan oleh pemerintah desa wantilan dam masyarakat desa wantilan.

Banyak ayat Al-Qur'an dan hadits nabi yang mendorong umat Islam bekerja mencari nafkah secara halal.

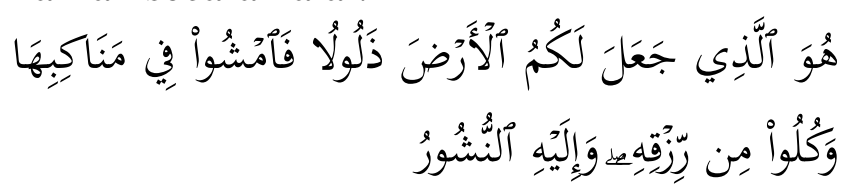

"Dialah Yang menjadikan bumi itu mudah bagi kamu, maka berjalanlah di segala penjurunya dan makanlah sebahagian dari rezeki-Nya. Dan hanya kepada-Nya-lah kamu (kembali setelah) dibangkitkan." (Q.S A1Mulk: 15)

Hadits:

"Sesungguhnya Allah mencintai hambahamba-Nya yang bekerja. Barang siapa yang bekerja keras mencari nafkah yang halal untuk keluarganya maka sama seperti mujahid di jalan Allah" (HR Ahmad). ${ }^{1}$

Dari wawancara yang dilakukan dengan Bapak Komarudin, S.Pd sebagai Kepala Desa Wantilan.

"Sebagian besar pengrajin adalah ibu rumah tangga yang memiliki waktu luang dan kemauan untuk berkreasi". ${ }^{2}$

\footnotetext{
2 Wawancara dengan bapak Komarudin,S,Pd pada tanggal 19 September 2019
}

\footnotetext{
${ }^{1}$ Muhammad Syafi'i Antonio, Bank Syariah dari teori ke praktik, 10
}

EKSISBANK (Ekonomi Syariah dan Bisnis Perbankan), Volume 5, Nomor 1, Juni 2021 
Di tangan beliau, para pengrajin di dampingi hingga pernah melakukan pameran ke tingkat kabupaten dan provinsi. Adapun pemasaran yang dilakukan saat ini selain melalui online di media sosial, juga melalui kumpulan kegiatan ibu-ibu dari bhayangkari, koramil dan ibu-ibu pejabat lainnya yang tertarik serta mendukung dengan produk tas yang di buat oleh masyarakat Desa Wantilan. Tidak hanya dalam penjualan, bapak kepala Desa Wantilan juga mengijinkan bagi siapa saja yang ingin belajar membuat tas dari limbah sendiri. Masyarakat di Desa Wantilan boleh ikut pelatihan secara grati s. Pelatihan ini biasanya di koordinir oleh ibu yuyu sebagai ketua kordinator.

\section{KESIMPULAN}

Setelah dilakukan kajian, analisis dan pembahasan sebelumnya atas permasalahan yang dirumuskan dan sesuai dengan tujuan penelitian, dapat ditarik kesimpulan sebagai berikut:

Praktik yang dilakukan pada pengolahan limbah industri di desa Wantilan adalah akad Hibah dengan besaran kontribusi uang senilai Rp.10.000,- per karungnya.

Pada pengolahan limbah industri di Desa Wantilan terdapat dua akad tabarru' dalam Bentuk memberikan sesuatu (giving something) yaitu akad hibah dan infaq yang sudah sesuai dengan ketentuan syariah.

Adapun manfaat akad Tabarru' yang sudah dilakukan diantaranya adalah:

a. Keuntungan hasil penjualan kerajinan cukup besar karena pengrajin tidak perlu membeli bahan baku.

b.Pengrajin dapat dengan mudah mendapatkan bahan baku karena sudah disediakan oleh pengelola.

c. Alat atau pengeluaran umum yang di perlukan oleh PKK untuk kemajuan bersama di bayarkan dari dana tabarru', adapaun keperluan tersebut diantaranya: pembuatan hangtag, keperluan pameran, Pembelian bahan baku (ke perusahaan selain PT AMB).

\section{DAFTAR PUSTAKA}

Alfin, Aidil, and Muhamad Rezi. 2019. "Komersialisasi Pupuk Kandang Dalam Prespektif Hukum Islam." Jurnal Mahkmah: Kajian Ilmu Hukum dan Hukum Islam 4(2).

Arifin, Zarul. 2021. "Jual Beli Barang Bekas Melalui Bank Sampah Perspektif Hukum Ekonomi Syariah." TERAJU: Jurnal Syariah dan Hukum 3(1).

Dewan Syariah Nasional. 2006. Akad Tabarru' Pada Asuransi Syariah. Indonesia.

Fauzan, Arif. 2016. "Prinsip Tabarru' Teori Dan Implementasi Di Perbankan Syariah.' Al-Amwal: Jurnal Kajian Ekonomi dan Perbankan Syariah 8(2): 400-411.

Hambali, Lili. 2019. "Pengolahan Limbah Industri Di Desa Wantilan Kecamatan Cipeundeuy Kabupaten Subang."

Mardani. 2015. Fiqh Ekonomi Syariah; Fiqh Muamalah. 1st ed. Jakarta: Kencana.

Nasir, Muhammad, Edy Purwo Saputro, and Sih Handayani. 2015. "Manajemen Pengelolaan Limbah Industri." BENEFIT: Jurnal Manajemen dan Bisnis 19(2).

Nurhasni, Zainus Salimin, and Ira Nurifitriyani. 2013. "Pengolahan Limbah Industri Elektroplating Dengan Proses Koagulasi Flokulasi." Prosiding Seminar SEMITARA FMIPA 1(1).

Oktayani, Dewi. 2018. "Konsep Tolong Menolong Dalam Asuransi Syariah.” IQTISHADUNA: Jurnal Ilmiah Ekonomi Kita 7(1): 39-50.

Rafsanjani, Haqiqi. 2016. "Akad Tabarru' Dalam Transaksi Bisnis." Jurnal Ekonomi dan Perbankan Syariah Vol 1,

EKSISBANK (Ekonomi Syariah dan Bisnis Perbankan), Volume 5, Nomor 1, Juni 2021 
No(1): 101-29. http://journal.umarticle/view/30756.

surabaya.ac.id/index.php/Mas.

Safitri, Eny, and Bustami Bustami. 2021. "Akad Syariah Pada Usaha Bank Sampah Aisyiyah Di Desa Sejegi Kabupaten Mempawah." JMI: Jurnal Muamalat Indonesia 1(1).

Santoso, Ratna Endah, and Nidyah Widyamurti. 2020. "Model Pengolahan Limbah Plastik OPP Laminasi Menjadi Produk Aksesoris Fesyen." Proceedings National Conference PKM Center 1(1).

Subhan, Moh. 2020. "Eksistensi Dan Optimalisasi Badan Usaha Milik Desa (BUMDes) Berbasis Syar'i Menuju Desa Sejahtera Mandiri." REVENUE: Jurnal Ekonomi Pembangunan dan Ekonomi Syari'ah 3(2).

Sugiyono. 2006. Metode Penelitian Pendidikan : Pendekatan Kuantitatif Dan Kualitatif Dan R\&D. Bandung: Alfabeta.

- 2013. Metodelogi Penelitian Kuantitatif, Kualitatif Dan $R \& D$. Bandung: Alfabeta.

- 2015. Metode Penelitian Kuantitatif, Kualitatif Dan R\&D. Bandung: Alfabeta.

- 2017. Statistika Untuk Penelitian. Bandung: Alfabeta.

- 2018. Metode Penelitian Kuantitatif, Kualitatif, Dan R\&D. Bandung: Alfabeta.

Yuyun. 2019. "Pengolahan Limbah Industri Di Desa Wantilan Kecamatan Cipeundeuy Kabupaten Subang."

Zulkarnain, Imam, Harianto Harianto, and Kirbrandoko Kirbrandoko. 2020. "Strategi Pemasaran Pengelolaan Limbah Medis Pada Pt. Prasadha Pamunah Limbah Industri (PPLI)." Jurnal Aplikasi Bisnis dan Manajemen. https://journal.ipb.ac.id/index.php/jabm/ 